\title{
Effect of Protease Enzyme on the Growth Performance and Carcass Traits of Broilers Fed with DDGS Supplemented Diet
}

\author{
Sonu*, Zile Singh Sihag, Parveen Kumar Ahlawat and Rajesh Dalal \\ Department of Animal Nutrition Lala Lajpat Rai University of Veterinary and Animal \\ Sciences, Hisar-125004, Haryana, India \\ *Corresponding author
}

\begin{tabular}{|l|}
\hline K e y w o r d s \\
$\begin{array}{l}\text { Broilers, Carcass traits, } \\
\text { Distillers dried grains } \\
\text { soluble (DDGS), Protease } \\
\text { enzyme }\end{array}$ \\
\hline Article Info \\
\hline $\begin{array}{l}\text { Accepted: } \\
\text { 20 April } 2018 \\
\text { Available Online: } \\
\text { 10 May } 2018\end{array}$ \\
\hline
\end{tabular}

A B S T R A C T
An experiment of six weeks period was conducted to evaluate the effect of supplementing enzymes in soybean replaced with DDGS based diet on the performance and carcass characteristics of broiler chicks. The experimental work was conducted on 280 day old commercial broiler chickens randomly divided into seven dietary treatments having two replicates with twenty birds in each replicate, in each treatment group. Basal diet according to BIS (2007) was formulated by taking maize and soybean meal as main ingredients and was offered to control group $\left(T_{1}\right)$, while treatment groups $T_{2}, T_{3}$ and $T_{4}$ were supplemented with 15,30 and $45 \%$ DDGS respectively, and $\mathrm{T}_{5}, \mathrm{~T}_{6}$ and $\mathrm{T}_{7}$ were supplemented with protease enzyme @ 0.25\% along with replacement of DDGS @ of 15,30 and 45\% respectively. The record of feed intake was done weekly on per replicate basis. The overall feed intake differed significantly $(\mathrm{P}<0.05) . \mathrm{T}_{4}$ and $\mathrm{T}_{7}$ groups having $45 \%$ DDGS replacement level with or without enzyme supplementation had higher $(\mathrm{P}<0.05)$ feed intake as compared to control diet. It was also observed that at $30 \%$ DDGS replacement level, body weight gain was significantly higher $(\mathrm{P}<0.05)$ due to addition of protease enzyme as compared to other dietary treatments. No significant effect observed on carcass traits of birds.

\section{Introduction}

The poultry sector showed marked extension in all the regions of country during the recent years. Such a huge success in the poultry farming business mostly depends on feeding quality, feed and feed formulation system. The proportion of feed cost in a broiler's ration ranges from 60 to $70 \%$ of the total cost of production. So, it is imperative to feed the birds with good quality and balanced ration with least cost formulation. By products of grains have a great health value and suitable for feeding the poultry birds. DDGS is a coproduct of ethanol production plants that use corn for manufacturing. During the yeast fermentation in ethanol plants, corn is ground, mixed with water, cooked and the liquefied starch from this process is hydrolysed and fermented to produce ethanol and $\mathrm{CO}_{2}$. As a result the non-fermentable components of this process which are rich in essential nutrients such as protein, fat, fibre, vitamins and minerals are recovered in a highly concentrated form as Distillers Dried Grains with solubles. The sudden increased demand 
for bio-fuels by the use of grain resources for ethanol production, has led to increased supply of distillers' dried grains with solubles (DDGS). So, this by-product of the ethanol production industry has drawn the significant attention of feed manufacturing industry to be incorporated into poultry diets (Barekatain et al., 2013a). Extensive documentation on DDGS has shown that it has a lower amino acid digestibility in poultry as compared to the parent grain. Enzymes have been used for more than 20 years in poultry feed, mainly to improve the energy utilization in cereals with high soluble non-starch-polysaccharides (NSP) levels. Feed enzymes have become an important tool to increase the nutritional value of feed ingredients, reduce feed costs, improve the environment, all while maintaining or improving poultry performance. Protease is a protein digesting enzyme that breaks down storage proteins binding starch within feed ingredients. Proteases are also effective in releasing protein anti-nutrients found in ingredients like soybean meal. This function of proteases makes proteins more available. The use of protease is capable of increasing the solubility of soybean meal protein, decreasing the effect of trypsin inhibitors (Caine et al., 1998) and improving amino acid digestibility (Bernard and McNab, 1997). Ghazi et al., (2002) found that adding different sources of Protease could increase true metabolizable energy (TME) and true nitrogen digestibility in chickens, with large differences among Protease sources. Olukosi et al., (2010) also reported that a mixture of carbohydrases and proteases was not as effective in improving the bird's performance, fed DDGS-containing diets although it improved the performance of the control birds, which were fed a low-density diet. Some contradictory reports with regard to the influence of protease on broiler performance were reported irrespective of DDGS inclusion. In a recent study by Kalmendal and Tauson (2012) observed an improvement in FCR in broilers, fed diets supplemented with xylanase and protease individually or in combination with no sub-additive effect of the enzymes. Using enzyme protease as a sole treatment, the bird's live performance and crude protein (CP) digestibility were also improved upto some level (Angel et al., 2011). Keeping the above facts in view, the present investigation was conducted with the objectives to study the growth performance of broilers in terms of body weight gain and feed efficiency and to know the nutrient digestibility, carcass characteristics of broiler diets.

\section{Materials and Methods}

All experimental procedures have been conducted in accordance with the guidelines laid down by Institutional Ethics Committee. The diets were formulated to meet the minimum requirement of broiler chickens to investigate the interaction of protease enzyme $(25 \mathrm{~g} / \mathrm{Kg})$ and varying levels of DDGS replacement. 280 day old broiler chicks were kept hygienically on floor litter/ deep litter system and proper vaccination programme has been followed with standard scientific protocols, at poultry farm Department of Animal Nutrition, College of Animal Husbandry and Veterinary Sciences, LUVAS, Hisar. Different records like feed offered, residual amount of feed and body weight were maintained weekly for each replicate to calculate the feed consumption per bird. The record was maintained up to 6 weeks of age. Seven diets were formulated for each growth period and maize-soya based diet was computed as per BIS (2007) specifications to meet out nutrient requirements to serve as control. $\mathrm{CP}$ and $\mathrm{ME}$ requirements during starter (0-3 weeks) and finisher (3 - 6 weeks) phases are 22 and 20\%; and 3100 and 3200 $\mathrm{kcal} / \mathrm{kg}$, respectively. The control group $\left(\mathrm{T}_{1}\right)$ was formulated by incorporation of maize and soybean ingredients while in treatment groups $\mathrm{T}_{2}, \mathrm{~T}_{3}$ and $\mathrm{T}_{4}$ soybean was replaced with 
DDGS @ 15, 30 and 45\%, respectively. Treatment groups $\mathrm{T}_{5}, \mathrm{~T}_{6}$ and $\mathrm{T}_{7}$ were formulated by addition of enzyme protease @ $25 \mathrm{~g} / 100 \mathrm{~kg}$ of feed along with 15, 30 and $45 \%$ DDGS level. Computation of Feed Conversion Ratio (FCR) for each replicate was done as follows: FCR=Total feed consumed $(\mathrm{g}) /$ Total body weight gain $(\mathrm{g})$. After recording their live weights, the randomly selected birds were sacrificed by severing the jugular vein and allowed them to bleed completely following 'Halal' method. Head was removed at the atlanto-occipital joint and shank at hock joint. Dressed weight thus obtained was recorded as follows: Dressed weight $=$ Live weight blood, feathers, head, shank and skin losses. Dressing percentage was calculated as by using the formula; Dressed weight/ Live weight $\times 100$. Dressed birds were then eviscerated by removing the crop, trachea and viscera as a whole. The eviscerated, drawn weights were recorded. Eviscerated and drawn percentage was calculated as: Eviscerated weight $=$ Dressed weight - weight of viscera and eviscerated percentage was calculated by Eviscerated weight/ Live weight× 100 .

Drawn weight was estimated by adding eviscerated weight and weight of giblets and drawn percentage was evaluated by drawn weight/live weight $\times 100$. Separate weights of liver, gizzard, heart, abdominal fat were also recorded after washing and bloating, and their relative weights (percentage of live weight) were then calculated. Breast and thigh muscle samples were also taken from each of the slaughtered birds and these were stored in deep-freeze separately for further chemical analysis. Data was analyzed statistically by general linear model procedure of statistical package for social sciences $20^{\text {th }}$ version (SPSS). Analysis of variance (ANOVA) was used to study the differences among treatment means and they were compared by using Duncan's Multiple Range Test (DMRT) as modified by Kramer (1955) at $\mathrm{P}<0.05$.

\section{Results and Discussion}

The ingredients and chemical composition of basal diet has been represented in Table 1. The data depicting feed intake in broiler chicken at 6 weeks of age under different dietary treatments is presented in Table 2. Feed intake was recorded weekly on per replicate basis and overall feed intake was differed significantly $(\mathrm{P}<0.05)$. Treatment groups $\mathrm{T}_{4}$ and $\mathrm{T}_{7}$ had significantly $(\mathrm{P}<0.05)$ higher feed intake as compared to control diet. A noticeable effect of enzyme and DDGS supplementation was observed during overall feed intake and the diet containing 30\% DDGS with enzyme protease which had a significantly $(\mathrm{P}<0.05)$ lower feed intake (3755.71) as compared to other dietary treatment groups.

The findings of the research work revealed that the average value of total feed intake during the entire experimental period i.e. 0-42 days did not differ significantly $(\mathrm{P}<0.05)$ upto $30 \%$ replacement of protein source viz. soybean meal with DDGS. However at $45 \%$ replacement levels the feed intake was higher $(\mathrm{P}<0.05)$ as compared to control as well as other dietary regime. Similar findings were also noticed by Barekatain et al., (2013b) who reported that at higher level of feeding of DDGS to broiler birds the intake was increased which could be attributed to the higher NSP at higher DDGS replacement levels.

It was reported that body weight gain (g) among various treatment groups differed significantly $(\mathrm{P}<0.05)$ and at $30 \%$ DDGS replacement level, body weight gain was significantly higher $(\mathrm{P}<0.05)$ due to addition of protease enzyme as compared to the diet having no enzyme. So, positive interaction of enzyme was noticed on body weight gain when DDGS replacer diet was given to broiler chickens. 
Table.1 Ingredient and chemical composition (\% DM basis) of basal diet

\begin{tabular}{|l|c|c|}
\hline Feed ingredient & Starter diet & Finisher diet \\
\hline Maize (kg) & 57 & 63 \\
\hline Soybean (kg) & 31 & 25 \\
\hline Fish meal (kg) & 8 & 7 \\
\hline Vegetable oil (kg) & 2 & 3 \\
\hline Mineral mixture (kg) & 2 & 2 \\
\hline Feed additive (g) & 320 & 320 \\
\hline Protease Enzyme (g) & 25 & 25 \\
\hline & & \\
\hline CP \% & Chemical composition & 21.32 \\
\hline CF \% & 23.18 & 3.26 \\
\hline EE \% & 4.42 & 5.15 \\
\hline Total ash \% & 3.84 & 8.74 \\
\hline Metabolizable energy** (Kcal/kg) & 8.78 & 3174.25 \\
\hline
\end{tabular}

*Feed additives include Meriplex-20g, Vitamin, Ventrimix-25g, Coccidiostat (Dinitro-0-Toluamide)-50g, Choline chloride-50g, Lysine-50g, DL-methionine-100g, CTC-25g and enzyme phytase-25g.

** Calculated values (Singh and Panda, 1988)

Table.2 Feed intake (g/bird) during different growth period under different dietary treatments

\begin{tabular}{|l|l|l|l|l|}
\hline Treatments & 0-2 week & 3-4 week & 5-6 week & 0-6 week \\
\hline $\mathrm{T}_{1}$ & $352.05 \pm 3.04$ & $1288.08^{\mathrm{b}} \pm 16.59$ & $2448.27^{\mathrm{b}} \pm 25.63$ & $4088.40^{\mathrm{b}} \pm 46.15$ \\
\hline $\mathrm{T}_{2}$ & $342.41 \pm 1.43$ & $1281.45^{\mathrm{b}} \pm 13.15$ & $2433.73^{\mathrm{bc}} \pm 28.94$ & $4057.59^{\mathrm{b}} \pm 32.37$ \\
\hline $\mathrm{T}_{3}$ & $345.09 \pm 2.75$ & $1254.13^{\mathrm{b}} \pm 11.86$ & $2428.85^{\mathrm{bc}} \pm 23.16$ & $4028.07^{\mathrm{b}} \pm 35.56$ \\
\hline $\mathrm{T}_{4}$ & $360.22 \pm 2.42$ & $1376.73^{\mathrm{a}} \pm 13.26$ & $2588.18^{\mathrm{a}} \pm 25.41$ & $4293.13^{\mathrm{a}} \pm 49.03$ \\
\hline $\mathrm{T}_{5}$ & $349.64 \pm 3.14$ & $1267.08^{\mathrm{b}} \pm 16.47$ & $2423.61^{\mathrm{bc}} \pm 35.23$ & $4040.33^{\mathrm{b}} \pm 30.84$ \\
\hline $\mathrm{T}_{6}$ & $341.05 \pm 2.11$ & $1221.49^{\mathrm{c}} \pm 19.81$ & $2193.17^{\mathrm{d}} \pm 38.78$ & $3755.71^{\mathrm{c}} \pm 27.92$ \\
\hline $\mathrm{T}_{7}$ & $359.18 \pm 3.63$ & $1367.90^{\mathrm{a}} \pm 17.54$ & $2577.33^{\mathrm{a}} \pm 38.11$ & $4277.41^{\mathrm{a}} \pm 40.19$ \\
\hline
\end{tabular}

Means bearing different superscripts in a column, differ significantly $(\mathrm{P}<0.05)$

Table.3 Effect of replacement of soybean meal with DDGS on average body weight gain (g/bird) during different growth period supplemented with protease enzyme

\begin{tabular}{|l|l|l|l|l|}
\hline Treatments & $0-2 w k$ & $3-4 w k$ & 5-6 wk & 0-6 wk \\
\hline $\mathrm{T}_{1}$ & $237.06^{\mathrm{a}} \pm 8.34$ & $838.47 \pm 12.05$ & $1359.23^{\mathrm{b}} \pm 22.62$ & $2434.76^{\mathrm{b}} \pm 33.45$ \\
\hline $\mathrm{T}_{2}$ & $224.67^{\mathrm{b}} \pm 7.75$ & $847.44 \pm 17.27$ & $1350.34^{\mathrm{b}} \pm 25.90$ & $2422.45^{\mathrm{b}} \pm 34.95$ \\
\hline $\mathrm{T}_{3}$ & $227.58^{\mathrm{ab}} \pm 9.88$ & $847.41 \pm 15.75$ & $1392.02^{\mathrm{b}} \pm 29.18$ & $2467.01^{\mathrm{b}} \pm 49.01$ \\
\hline $\mathrm{T}_{4}$ & $216.04^{\mathrm{c}} \pm 8.29$ & $789.26 \pm 13.61$ & $1264.07^{\mathrm{c}} \pm 26.01$ & $2269.37^{\mathrm{c}} \pm 46.33$ \\
\hline $\mathrm{T}_{8}$ & $226.80^{\mathrm{ab}} \pm 6.01$ & $843.25 \pm 13.59$ & $1367.68^{\mathrm{b}} \pm 36.57$ & $2437.73^{\mathrm{b}} \pm 57.89$ \\
\hline $\mathrm{T}_{9}$ & $234.57^{\mathrm{a}} \pm 9.08$ & $895.38 \pm 15.74$ & $1465.27^{\mathrm{a}} \pm 27.79$ & $2595.22^{\mathrm{a}} \pm 35.40$ \\
\hline $\mathrm{T}_{10}$ & $215.10^{\mathrm{c}} \pm 7.96$ & $781.42 \pm 16.59$ & $1274.90^{\mathrm{c}} \pm 28.81$ & $2271.41^{\mathrm{c}} \pm 28.02$ \\
\hline
\end{tabular}

Means bearing different superscripts in a column, differ significantly $(\mathrm{P}<0.05)$ 
Table.4 Feed conversion ratio (FCR) during different growth period under different dietary regime

\begin{tabular}{|l|l|l|l|l|}
\hline Treatment & $0-2$ week & 3-4 week & 5-6 week & $0-6$ week \\
\hline $\mathrm{T}_{1}$ & $1.48^{\mathrm{ab}} \pm 0.01$ & $1.53^{\mathrm{c}} \pm 0.02$ & $1.80^{\mathrm{d}} \pm 0.03$ & $1.68^{\mathrm{c}} \pm 0.04$ \\
\hline $\mathrm{T}_{2}$ & $1.52^{\mathrm{b}} \pm 0.01$ & $1.51^{\mathrm{bc}} \pm 0.01$ & $1.82^{\mathrm{d}} \pm 0.02$ & $1.67^{\mathrm{bc}} \pm 0.02$ \\
\hline $\mathrm{T}_{3}$ & $1.51^{\mathrm{ab}} \pm 0.02$ & $1.47^{\mathrm{b}} \pm 0.02$ & $1.74^{\mathrm{c}^{\mathrm{c}}} \pm 0.01$ & $1.63^{\mathrm{bc}} \pm 0.04$ \\
\hline $\mathrm{T}_{4}$ & $1.52^{\mathrm{b}} \pm 0.02$ & $1.74^{\mathrm{d}} \pm 0.04$ & $2.04^{\mathrm{e}} \pm 0.03$ & $1.89^{\mathrm{e}} \pm 0.06$ \\
\hline $\mathrm{T}_{5}$ & $1.55^{\mathrm{b}} \pm 0.01$ & $1.50^{\mathrm{bc}} \pm 0.01$ & $1.77^{\mathrm{cd}} \pm 0.02$ & $1.65^{\mathrm{bc}} \pm 0.06$ \\
\hline $\mathrm{T}_{6}$ & $1.45^{\mathrm{a}} \pm 0.02$ & $1.36^{\mathrm{a}} \pm 0.02$ & $1.49^{\mathrm{a}} \pm 0.04$ & $1.44^{\mathrm{a}} \pm 0.05$ \\
\hline $\mathrm{T}_{7}$ & $1.50^{\mathrm{ab}} \pm 0.02$ & $1.75^{\mathrm{d}} \pm 0.03$ & $2.02^{\mathrm{e}} \pm 0.03$ & $1.88^{\mathrm{e}} \pm 0.02$ \\
\hline
\end{tabular}

Means bearing different superscripts in a column, differ significantly $(\mathrm{P}<0.05)$

Table.5 Composition (\%) of breast and thigh muscles in experimental birds under different dietary treatments

\begin{tabular}{|l|l|l|l|l|l|l|}
\hline \multirow{2}{*}{ Treatment } & \multicolumn{3}{|l|}{ Breast muscle } & \multicolumn{2}{l|}{ Thigh muscle } \\
& Moisture & Crude protein & Fat & Moisture & Crude protein & Fat \\
\hline $\mathrm{T}_{1}$ & $74.92 \pm 12.81$ & $19.35 \pm 1.87$ & $5.14 \pm 0.51$ & $75.52 \pm 12.86$ & $18.62 \pm 2.90$ & $7.02 \pm 0.96$ \\
\hline $\mathrm{T}_{2}$ & $74.54 \pm 14.47$ & $19.18 \pm 3.03$ & $5.23 \pm 0.73$ & $75.23 \pm 16.66$ & $18.58 \pm 3.01$ & $7.08 \pm 0.85$ \\
\hline $\mathrm{T}_{3}$ & $75.05 \pm 16.71$ & $19.44 \pm 2.88$ & $5.19 \pm 0.67$ & $76.24 \pm 15.52$ & $18.69 \pm 1.89$ & $7.06 \pm 0.89$ \\
\hline $\mathrm{T}_{4}$ & $74.35 \pm 11.72$ & $19.08 \pm 2.98$ & $5.32 \pm 0.64$ & $75.63 \pm 11.73$ & $18.42 \pm 3.27$ & $7.25 \pm 0.83$ \\
\hline $\mathrm{T}_{5}$ & $74.77 \pm 12.86$ & $19.32 \pm 3.85$ & $5.14 \pm 0.62$ & $75.56 \pm 14.89$ & $18.53 \pm 2.95$ & $7.11 \pm 0.91$ \\
\hline $\mathrm{T}_{6}$ & $75.26 \pm 14.52$ & $19.85 \pm 4.70$ & $5.10 \pm 0.79$ & $76.39 \pm 11.83$ & $19.04 \pm 2.34$ & $7.01 \pm 0.89$ \\
\hline $\mathrm{T}_{7}$ & $\mathbf{7 4 . 1 2 \pm 1 6 . 7 0}$ & $19.26 \pm 2.95$ & $\mathbf{5 . 1 5} \pm 0.69$ & $\mathbf{7 5 . 3 2} \pm \mathbf{1 3 . 7 6}$ & $\mathbf{1 8 . 2 5} \pm 3.50$ & $7.37 \pm 0.92$ \\
\hline
\end{tabular}

Table.6 Dressed, eviscerated, drawn yield and weight of giblets of the experimental birds under different dietary treatments

\begin{tabular}{|l|l|l|l|l|l|l|l|}
\hline Treatments & $\begin{array}{l}\text { Dressed } \\
(\%)\end{array}$ & $\begin{array}{l}\text { Eviscerated } \\
(\%)\end{array}$ & $\begin{array}{l}\text { Drawn } \\
(\%)\end{array}$ & $\begin{array}{l}\text { Liver } \\
(\%)\end{array}$ & $\begin{array}{l}\text { Heart } \\
(\%)\end{array}$ & $\begin{array}{l}\text { Giward } \\
(\%)\end{array}$ & $\begin{array}{l}\text { Giblet } \\
(\%)\end{array}$ \\
\hline $\mathrm{T}_{1}$ & $71.17 \pm 6.96$ & $63.23 \pm 1.56$ & $68.10 \pm 4.06$ & $2.57 \pm 0.66$ & $0.56 \pm 0.44$ & $1.74 \pm 0.21$ & $4.87 \pm 1.06$ \\
\hline $\mathrm{T}_{2}$ & $70.12 \pm 6.88$ & $62.18 \pm 2.15$ & $66.93 \pm 2.33$ & $2.55 \pm 0.63$ & $0.50 \pm 0.08$ & $1.70 \pm 0.34$ & $4.75 \pm 1.02$ \\
\hline $\mathrm{T}_{3}$ & $69.32 \pm 4.45$ & $61.43 \pm 6.12$ & $66.13 \pm 5.12$ & $2.46 \pm 0.42$ & $0.51 \pm 0.08$ & $1.73 \pm 0.14$ & $4.70 \pm 0.91$ \\
\hline $\mathrm{T}_{4}$ & $68.97 \pm 7.62$ & $60.38 \pm 5.07$ & $65.06 \pm 1.15$ & $2.50 \pm 0.38$ & $0.49 \pm 0.39$ & $1.69 \pm 0.44$ & $4.68 \pm 0.92$ \\
\hline $\mathrm{T}_{5}$ & $70.25 \pm 8.28$ & $61.34 \pm 2.93$ & $66.12 \pm 5.38$ & $2.52 \pm 0.65$ & $0.47 \pm 0.06$ & $1.69 \pm 0.61$ & $4.78 \pm 0.95$ \\
\hline $\mathrm{T}_{6}$ & $72.34 \pm 6.58$ & $63.56 \pm 4.68$ & $68.44 \pm 2.24$ & $2.57 \pm 0.48$ & $0.56 \pm 0.03$ & $1.75 \pm 0.39$ & $4.88 \pm 1.15$ \\
\hline $\mathrm{T}_{7}$ & $68.84 \pm 4.24$ & $60.56 \pm 6.31$ & $65.24 \pm 4.46$ & $2.48 \pm 0.42$ & $0.54 \pm 0.02$ & $1.66 \pm 0.35$ & $4.68 \pm 0.97$ \\
\hline
\end{tabular}

This improvement in body weight and weight gain might be due to enhanced available protein by degradation of amino acid content and increased availability of muscle protein by enzyme supplementation.
There was no effect of adding enzyme to diet on feed conversion ratio in general but poor FCR was reported at $45 \%$ DDGS fed groups during whole experimental period. The FCR was lowest (1.44) at 30\% DDGS level 
supplemented with protease enzyme but no effect of addition of enzyme at 45\% DDGS level was reported during overall period of research. The results are in agreement with those of Arce et al., (2010) who reported that addition of protease enzyme in broiler diet containing maize-soybean-DDGS yielded the best results in term of FCR. The findings of the study were also similar to those of Yan et al., (2012) who also reported that addition of protease enzymes in the diets of broilers improved FCR.

Difference in moisture and crude protein content in breast as well as thigh muscle of all DDGS supplemented dietary treatments was non-significant compared to control groups and no effect of enzyme supplementation was observed. CP content of breast muscle was higher than that of the thigh muscle which is a genetic trait of the different muscles of body. The effect of feeding DDGS and enzyme was reported non-significant on $\mathrm{EE}$ content of breast and thigh muscle. The content of ether extract was higher in thigh muscle as compared to breast muscle. But results showed that there was no adverse effect of replacing soybean meal with DDGS up to $45 \%$ level on the qualitative values of the carcass traits. These results are similar to the study of Choi et al., (2008), who has been reported that there was no negative effect seen up to $15 \%$ DDGS supplemented diet on meat qualities of thigh and breast muscle of broiler birds. There was no significant effect of supplementing enzymes on the carcass traits of broiler birds.

Up to $30 \%$ replacement level of DDGS, no any adverse effect was noticed on carcass traits. The differences in dressing percentage of treatment groups differed non-significantly and no effect of addition of enzyme was presented by the estimated data. Eviscerated percentage values in different treatments containing various DDGS levels were almost similar and differed non significantly. Drawn yield, which includes eviscerated weight and the giblets weight, was non-significant. However the drawn yield was lower numerically at $45 \%$ DDGS replacement level but effect of enzyme supplementation was non- significant. The values of giblets (includes heart, liver and gizzard) were also similar to drawn yield and the percentage weight of the heart, liver and gizzard was non- significant.

The results of current study are in accordance with that of Ghazalah et al., (2012), who reported that there was no significant effect on carcass traits up to $60 \%$ replacement of soybean meal with DDGS. The results of Swaitkiewicz and Koreleski (2006) were also similar to the present study as the dressing yield was not affected by the addition of DDGS or by the addition of additives (xylanase and phytase) to the diets with high levels of DDGS (Table 3-6).

It may be concluded that the supplementation of protease enzyme is beneficial when DDGS is replaced at $30 \%$ level. No harmful effect has been observed on performance and carcass trait of broiler chicken at any level of DDGS replacement.

\section{References}

Angel, C., Saylor, W., Vieira, S., and Ward, N., 2011. Effects of a mono component protease on performance and protein utilization in 7-to 22-day-old broiler chickens. Poult. Sci. 90: 2281-2286.

Arce, J., Avila, E., Rosales, E., Charraga, S., Fernández, S., R., 2010. Effect of adding protease and xylanase feed enzymes activities on broilers fed cornSBM-DDGS diets. Int. Poul. Sci. Atlanta, US. T: 108.

Barekatain, M. R., Antipatis, C., Choct, M. and Iji, P. A., 2013a. Interaction 
between protease and xylanase in broiler chicken diets containing sorghum distillers' dried grains with solubles. Ani. Feed Sci. and Tech. 182: $71-81$.

Barekatain, M. R., Antipatis, C., Rodgers, N., Walkden-Brown, S. W., Iji, P. A. and Choct, M., 2013b. Evaluation of high dietary inclusion of distillers dried grains with solubles and supplementation of protease and xylanase in the diets of broiler chickens under necrotic enteritis challenge. Poul. Sci. 92: 1579-1594.

BIS. Bureau of Indian Standards, Poultry Feed Specification, $5^{\text {th }}$ revision. Manak Bhawan, 9 Bahadur Shah Zafar Marg, New Delhi. 2007.

Choi, Lee, H., S., Shin, H., L., Cheorun, M., H., J., Lee, S., K., Lee, B., D., 2008. Nutritive and economic values of corn distillers dried grains with solubles in broilers diets. Asian- Aust. J. of Ani. Sci. 21 (3): 414-419.

Cowieson, A., J., Singh, D., N., Adeola, O., 1995. Prediction of ingredient quality and the effect of a combination of xylanase, amylase, protease and phytase in the diets of broiler chicks. Energy and nutrient utilisation. Br. Poult. Sci. 47: 490-500.

Duncan, D., B., 1955. Multiple range and multiple F tests. Biometrics. 11: 1-42.

Ghazalah, A., A., Abd. Elsamee, M., O., Abd El-Hakim, A., S., Ibrahim, M., M., 2012. Evaluation of using Distillers Dried Grains with Solubles (DDGS) in broiler diets. Egyp. Poult. Sci. 32: 381397.
Ghazi, S., Rooke, J., A., Galbraith, H., 2003. Improvement of the nutritive value of soybean meal by protease and beta galactosidase treatment in broiler cockerels and broiler chicks. Br. Poult. Sci. 44: 410-418.

Kalmendal, R., Tauson, R., 2012. Effects of a xylanase and protease, individually or in combination, and an ionophore coccidiostat on performance, nutrient utilization, and intestinal morphology in broiler chickens fed a wheat-soybean meal-based diet. Poult. Sci. 91: 13871393.

Olukosi, C., M., Cowieson, A., J., Adeola, A., 2010. Broiler responses to supplementation of phytase and admixture of carbohydrases and phytase in maize soybean meal diets with or without maize distillers' dried grain with solubles. Br. Poult. Sci. 51: 434443.

SPSS version 17.0. Statistical packages for Social Sciences, Version 17.0, SPSS Inc., Illinois, USA. 2008.

Swaitkiewicz, S., Koreeleski, J., 2008. The use of distillers dried grains with solubles (DDGS) in poultry nutrition. World's Poult. Sci. J. 64: 257-265.

Yan, F., Garribay, L., Acre, J., Lopes, Coello, C., Camacho, D., Disbennet, P., Vazquez-Anon, M., Manangi, M., Odentallah, N., Carter, S., 2012. Effect of protease supplementation on broiler performance and in-vitro protein digestibility. Poul. Sci. Sympo. 8: 134137.

\section{How to cite this article:}

Sonu, Zile Singh Sihag, Parveen Kumar Ahlawat and Rajesh Dalal. 2018. Effect of Protease Enzyme on the Growth Performance and Carcass Traits of Broilers Fed with DDGS Supplemented Diet. Int.J.Curr.Microbiol.App.Sci. 7(05): 2713-2719.

doi: https://doi.org/10.20546/ijcmas.2018.705.314 